kolleger ganske godt, og jeg er overbevist om at svaret vil bli: «Vi kommer sent, men vi kommer godt, Herr Statsraad!»

Tore Midtvedt

Gjettum

\section{Regelrytteri eller kunnskapsstyrt praksis?}

Med utgangspunkt i en kommentar fra Gro Hillestad Thune (1) målbærer Ole Terland bekymringer for blåreseptordningen i Tidsskriftet nr. 12/2009 (2).

Statens legemiddelverk vedtar hvilke legemidler som kan forskrives direkte på blåresept i sin alminnelighet, og de gir politiske myndigheter råd om hvilke legemidler som skal godkjennes i blåreseptordningen. Til hjelp i dette arbeidet har Legemiddelverket bl.a. Blåreseptnemnda, som etter oppdrag fra Helse- og omsorgsdepartementet skal bistå Legemiddelverket med å utforme, utdype og kvalitetssikre grunnlaget for beslutninger om godkjenning av legemidler for refusjon. Nemnda er bredt sammensatt og inviterer alltid spesifikke kliniske eksperter til sine møter for å sikre et tilstrekkelig faglig fundament for de rådene som gis.

Det er en viktig og overordnet legemiddelpolitisk målsetting i Norge at befolkningen skal ha tilgang til sikre og virksomme legemidler uavhengig av betalingsevne. Samtidig er det en forutsetning for inklusjon i blåreseptordningen at legemidlene er kostnadseffektive, altså at de skal ha effekter som står i rimelig forhold til pris.

Ole Terland skriver blant annet følgende: «Jeg har mange ganger kommet i en etisk og medisinsk problemstilling: Dersom jeg følger regelverket, vil min pasient få en mindreverdig behandling, en behandling jeg selv aldri ville hatt, en behandling jeg ikke ville gitt min kone eller mine barn. Men min ubemidlede minstepensjonist må ta til takke med et slikt preparat uten at han eller hun har mulighet til å betale ekstra for å få et preparat som er i samsvar med beste medisinske praksis» (2).

Dette er interessante, for ikke å si oppsiktsvekkende påstander. Jeg vil be Terland om å konkretisere de etiske problemene han reiser. Når føler du at blåreseptordningen fremtvinger forskrivning av mindreverdig legemiddelbehandling, og hvilke terapiområder og legemidler sikter du til?

\section{Anne Elise Eggen}

Blåreseptnemnda

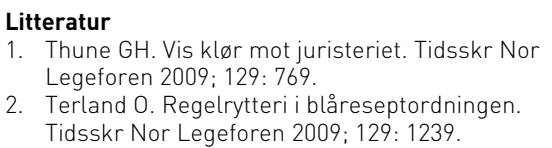

\section{Målrettet intervensjon senker keisersnittsraten}

Mette Christophersen Tollånes' artikkel i Tidsskriftet nr. 13-14/2009 om årsakene til og konsekvensene av den økte anvendelse av keisersnitt (1) har velfortjent utløst en debatt som vi håper fortsetter. I samme nummer har Annetine Staff en leder om keisersnitt som etter vårt skjønn er for vag, og som vi ønsker å kommentere nærmere. Det kan innledningsvis $\mathrm{i}$ hennes leder se ut som om økningen i bruk av keisersnitt reflekterer en tiltakende defensiv fødselshjelp og kvinnenes ønske om keisersnitt. Vi mener at det bare kan forklare en liten del av den økning vi har sett de siste årene. Staff skriver at det er ressurskrevende å redusere keisersnittsfrekvensen eller å unngå fortsatt økning. Det er riktig, men det er også ressurskrevende å lære operativ teknikk. Hvem ville bruke som innvending mot å tilegne seg den teknikk som kreves for avansert kreftkirurgi at det er ressurskrevende? Etter vårt beste skjønn er det ikke kvinnenes ønsker som er hovedgrunnen til den økning vi har sett de siste årene, heller at vi selv ikke har lagt tilstrekkelig vekt på kvalitet og opplæring i fødselshjelpen.

Gode indikasjoner for induksjon, tyding av elektronisk overvåking, vurdering av ristyrke og manuelle ferdigheter som gjør det mulig både å følge barnets kardinalbevegelser og å forløse mor krever løpende opplæring, teoretisk og praktisk. Den må omfatte både erfarne og mindre erfarne kolleger. Vi har sett at hyppig gjennomgang av aktuelle tilfeller, problemstillinger og rutiner er nødvendig, også for å skape felles forståelse og omforente holdninger i avdelingen. Opplæring og en felles viten om normale og patologiske fødselsforløp er forutsetninger for trygg fødselshjelp og bidrar til å skape enighet om indikasjoner for keisersnitt og andre obstetriske inngrep. Det er viktig at jordmødrene trekkes inn i dette arbeidet. Regelmessige fellesmøter med jordmødre om tolking av fosterets hjerteaktivitet under fødselen og praktiske øvelser på fantom er en del av denne løpende utdanningen. Faglig trygghet hos leger og jordmødre gir trygghet hos den gravide og den fødende.

Keisersnitt er et av våre viktigste virkemidler i fødselshjelpen, og fødselsangst skal tas alvorlig. Det er ikke nødvendigvis det samme som å bruke kniv. I Bergen har vi etter keisersnittsrater på mer enn $14 \%$ i 2001 og 2002 redusert andelen til vel 10\% de siste årene. Samtidig er antall barn født med metabolsk acidose svært lavt. En slik holdning til forløsning krever, med Staffs ord, også et kaldt hode og et varmt hjerte. Men det lar seg gjøre. Hun har rett $i$ at det er ressurskrevende. Som god medisin ofte er.

\author{
Susanne Albrechtsen \\ Kåre Augensen \\ Per E. Børdahl \\ Jörg Kessler \\ Haukeland universitetssykehus \\ Litteratur \\ 1. Tollånes MC. Økt forekomst av keisersnitt - \\ årsaker og konsekvenser. Tidsskr Nor Legeforen \\ 2009; 129: 1329-31. \\ 2. Staff A. Keisersnitt - til nytte eller skade? Tidsskr \\ Nor Legeforen 2009; 129: 1321.
}

\section{A. Staff svarer:}

Kolleger fra Kvinneklinikken ved Haukeland universitetssykehus illustrerer poenget med min leder (1): Det er mulig å snu tendensen med stadig flere keisersnitt i Norge, men dette krever målrettet arbeid. Kvinneklinikken på Haukeland er et godt forbilde i så måte, både nasjonalt og internasjonalt. At dårligere opplæring i fødselshjelp skulle være hovedgrunnen til at keisersnittsfrekvensen er økende her i landet, er antakelig vanskelig å dokumentere. Muligens mener forfatterne at dette også er hovedårsaken $i$ andre industrialiserte land?

Flere leger og kortere arbeidstid, både i Norge og andre industrialiserte land, sannsynliggjør at gynekologer får mindre erfaring i fødselshjelp enn i «gamle dager». Imidlertid er det $i$ dag en mer systematisk opplæring $\mathrm{i}$ og dels sertifisering $\mathrm{i}$ håndtering $\mathrm{av}$ obstetriske situasjoner, med for eksempel bruk av fantomer, CTG-opplæring (og annen elektronisk fosterovervåking), både for leger i spesialisering og for spesialister i gynekologi og obstetrikk samt for jordmødre. Kvinneklikken ved St. Olavs hospital har for eksempel de siste årene hatt et sertifiseringskurs, kalt «Advanced Life Support Training in Obstetrics» (ALSO), der både jordmødre, utdanningskandidater og gynekologer fra hele Norge deltar, etter mønster fra Storbritannia (2). Kurset benyttes i mange land.

Uansett årsakene til den økte keisersnittsfrekvensen er jeg selvsagt enig med forfatterne $i$ at god medisin er basis for alt vi foretar oss i obstetrikken og at systematisk opplæring av leger og jordmødre er en grunnpilar for å få en optimal keisersnittsfrekvens. Dette innebærer også en systematisk gjennomgang av indikasjon for ethvert keisersnitt, både elektive og akutte, ved alle landets kvinneklinikker.

Det er sannsynligvis mange forhold som gir flere keisersnitt i Norge og i verden for øvig. Kollegene fra Haukeland påpeker at bestrebelsene for å senke frekvensen av keisersnitt uten medisinsk indikasjon krever mye arbeid, men at det er god medisin for mor og barn. Jeg er helt enig med forfatterne $\mathrm{i}$ at dette arbeidet må styrkes, og støtter deres ønske om at denne debatten fortsetter.

\section{Annetine Staff}

Kvinneklinikken

Oslo universitetssykehus, Ullevål 